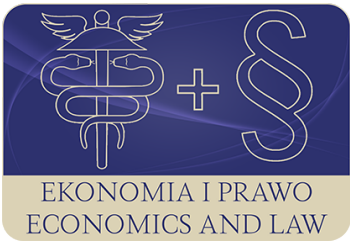

EKONOMIA I PRAWO. ECONOMICS AND LAW

Volume 16, Issue 3, September 2017

p-ISSN 1898-2255, e-ISSN 2392-1625

www.economicsandlaw.pl

EKONOMIA I PRAWO
ECONOMICS AND LAW

ORIGINAL ARTICLE

received 13.06.2017; revised 16.09.2017; accepted 30.09.2017

Citation: Poniatowicz, M. (2017). Transaction costs in the context of the requirements of effective finance management for local government units. Ekonomia i Prawo. Ecomomics and Law, 16(3):

325-341. doi:10.12775/EiP.2017.023.

\title{
Transaction costs in the context of the requirements of effective finance management for local government units
}

\author{
MARZANNA PONIATOWICZ \\ University of Bialystok, Faculty of Economics and Management, ul. Warszawska 63, \\ 15-062 Bialystok, Poland \\ $\square$ m.poniatowicz@uwb.edu.pl
}

\begin{abstract}
Motivation: Transaction costs economics fits in the paradigm of the new institutional economy, in which the costs are treated as a versatile measure for the effectiveness of institutions. Transaction costs are generated in every field of human activity, because we live 'in the world of contracts'. Characteristics of transaction costs include: common unawareness of their existence, difficulties in quantification and omission in economic calculation.

This pertains especially to the public sector and the corresponding public transaction costs. In modern public finance system, costs rise at a dynamic rate, thus having a significant effect on government budget, as well as on the effectiveness of the public sector. Aim: The purpose of this paper is to identify and indicate the specificity of public transaction costs for local government sub-sector, as an integral component of public finance sector. The intent of the author is to expose the threads of local governance and public sector within the theory of transaction costs economy, as well as to prove that inclusion of those costs in economic calculations related to local finance system is the necessary condition for effective management of self-government finance.

Results: The theoretical achievements of transaction costs economy focuse mainly on market transactions (market transaction costs) and managerial relations (managerial transaction costs), usually marginalizing the thread of public transaction costs occurring in the field of the institutional environment related to the process of making public choices/political decisions and providing of public goods. The highest transaction costs of self-government sub-sector are associated with two levels of its activity. First, contracts concluded at the public entity — public entity level, and second, contracts concluded at the public entity - private entities level. In the first case, it is about transaction costs re-
\end{abstract}


lated to the structure of public institutions, generated as an effect of fiscal relations among individual levels of public authority (transaction costs of intergovernmental relations). The second case is associated with the progressing marketization of relations within the pub-

lic sector, and the transaction costs associated with the process pertain among others to: the method of provision of local public goods (including consolidation of the entities rendering those services), tender procedures, the public-private partnership, privatization processes of municipal companies, municipal outsourcing, etc.

Keywords: transaction costs economics; public transaction costs; contract; local government JEL: D23; H7; H77

\section{Introduction}

The public sector and the associated sector of public finances become the subject of economic analyses in terms of the possibility of increasing the efficiency of their operation. However, transaction costs are an element that is clearly underestimated in such analyses. It is a concept with theoretical basis in the socalled New Institutional Economics - a doctrine of economics accepting the role of institutions in limiting uncertainty (North, 1990, p. 4).

The issue of transaction costs can be found in Polish literature mainly in regards to market transactions (market transaction costs) and managerial relations (managerial transaction costs). However, the thread of public transaction costs occurring in the field of the institutional environment related to the processes of decision-making in the public sector and provision of public goods, is significantly less frequently undertaken. This article attempts at filling this gap.

The objective of this paper is to approximate the institutional approach in the context of public management. Its purpose is to identify and indicate the specificity of public transaction costs in local government units as subjects of the public finance sector (general government). The paper demonstrates that allowing for such costs in economic calculations connected to the system of local finances is a necessary condition for efficient management of local government finances and, consequently, increased efficiency of the public sector.

\section{Research methodology}

This paper compares the theoretical achievements of the New Institutional Economics, with particular emphasis on the Transaction Costs Theory, with the postulations of the New Public Management concept, which is based on the idea of managerialism in the public sector. This allows the author to demonstrate the specificity and diversity of transaction costs incurred by local government, as well as to determine the possibilities and planes of utilization of the postulations of the Transaction Costs Theory in the contexts of efficient management of finances for local government units. 


\section{Effective finance management for local government units and the paradigm of new institutional economics: literature review}

The sector of public finances contains organizational units which perform public tasks and are financed by public means. An integral component of the sector of public finances, aside from the governmental sub-sector and the sub-sector of social insurance, is the local government sub-sector. In Poland, it predominantly consists of local government units - the so-called LGUs (2478 municipalities, including 66 cities with poviat rights, 314 poviats, 16 local government voivodeships), as well as the associated organizational bodies (e.g., local government budgetary bodies, local government budgetary plants, local government public health care facilities, local government culture institutions, local government legal persons established on the basis of separate laws) (Public Finances Act, 2007).

According to data for 2015, total budgetary incomes of local government sub-sector in Poland amounted to PLN 245.7 billion (including LGU's incomes - PLN 199 billion), constituting over 25\% of total incomes of the whole sector of public finances. Expenses amounted to PLN 242.2 billion (including LGU's expenses - PLN 196.4 billion), constituting approx. 24\% of total expenses of public finances. Total result of local government sub-sector amounts to PLN 3.5 billion (positive result - a budgetary surplus), including LGU's result - PLN 2.6 billion. However, the debt of local government sub-sector amounted to PLN 72.1 billion (including LGU's debt - PLN 71.6 billion), which amounted to $8.2 \%$ of total amount of public debt (debt after eliminating financial flows between entities from the public finances sector, meaning after consolidation) (Rada Ministrów, 2016, p. 297, 323).

Data demonstrates the significance of local government finances within the Polish system of public finances. In this context the idea of effective finance management takes special meaning. The New Public Management (NPM) concept, which is based on the idea of managerialism in the public sector, refers to it. The aforementioned concept accentuates specific similarities in the functioning of public administration to the private sector as well as exposes the significance of professional management and efficiency in the public sector. Proof of the growing popularity of the Polish NPM concept are many publications related to this issue (Zalewski, 2007; Lubińska, 2009; Krynicka, 2006, pp. 193-202; Supernat, 2003, pp. 28-46).

As literature on the subject emphasizes, increasing the efficiency of the public sector, including local government sub-sector, is not an easy process, since any changes realized within this field meet a series of obstacles, e.g., bureaucratic in nature, cultural, political, mental etc. In this context, the new institutional economics, by analyzing the impact of extra-economic factors in the economic processes taking place (social, cultural, historical, legal, political), may consti- 
tute a good theoretical base for analyses of the public sector, providing important arguments to justify and support reforms undertaken in this sector (Rudolf, 2015, p. 111).

The new institutional economics term was introduced to the reference literature by Oliver E. Williamson (1998a; 1998b), emphasizing the difference of the new approach in comparison with the so-called 'old institutionalism', often described as classical or historical institutionalism, whose representatives are mostly the American economists Thorstein B. Veblen and John R. Commons (Rosińska, 2008, p. 258). The first of them inaugurated the behavioral approach in economic analyses, focusing on the analysis of the impact of non-formal institutions (Veblen, 1899)'. John R. Commons (1957) focuses on formal institutions, including above all things on the judicial system.

The key theoretical concepts, coherent with the paradigm of the new institutional economics, and important from the standpoint of the possibility of a broader and interdisciplinary look at LGU's finances, are demonstrated in table 1.

Table 2 lists the most important postulations of effective public management (associated with the already mentioned new public management concept) in the context of the described theoretical concepts of the new institutional economics.

What is symptomatic, transaction costs theory relatively scarcely appears in Polish literature in the context of public sector and effective management of local finances. Most attention is devoted to the public choice theory (Wilkin, 2012). However, institutions and transaction costs are the key to understanding contemporary economic problems, also the ones related to the public sector and local governments. Minimization of such costs is still an undervalued aspect for local government economic decision-makers. One might suspect that the majority of the aforementioned decision-makers are not aware of the existence of transaction costs.

\section{Transaction costs in the new institutional economics: theoretical connotations}

In economic sciences, heterodoxical economics becomes more and more popular, promoting the need for an interdisciplinary approach in economic studies, allowing for a broader social-historical-cultural aspect (Woźniak-Jęchorek, 2014, p. 391). This thread also includes the already mentioned new institutional economics. It puts an emphasis on two key aspects.

1 Veblen (1988), in his book entitled The Theory of the Leisure Class: An Economic Study of Institutions discerned two types of institutions, i.e. producing institutions (the world of industry) and the associated labor class, as well as monetary institutions (the world of business) and the associated leisure class. He ascribed an instinct of workmanship to the former ones, and an instinct of greed and conspicuous consumption to the latter. 
The first are institutions. They can be divided into formal institutions (constitution, acts, regulations, and in the case of LGUs - also local law acts, statutes, organizational regulations of local government offices, etc.) and non-formal institutions (cultural, ordinary, ethical demeanors, religion etc.). In the doctrine in question, they are considered a key to understanding contemporary economic problems.

American economist Douglass Cecil North (1994, p. 359) defines them as a set of rules and regulations constituting specific limitations (legal, organizational, traditional etc.) for human behaviors. The author emphasizes that they create a structure for stimuli affecting the participants of the exchange, making the world more predictable (North, 1990, p. 3). Rudolf (2015, p. 113) points to the fact that such an understanding of institutions means they are, on one hand, more commonly accepted rules of behavior, and on the other hand they constitute specific limitations of choice. Those limitations may also pertain to public choices and public policy, including the shaping of relations between public, social and private organizations. Consequently, they may significantly affect the efficiency of the public sector ${ }^{2}$.

The second of the accentuated aspects in the new institutional economics are transaction costs. Economics of transaction costs deals with the exchange relations (transactions) between the entities of the institutional system of the economy. Those relations pertain both to the private and public sphere. In the latter case, they refer to transfer of public rights. In the transaction costs theory, the substantial costs are treated as only one of the universal measures for evaluation of the efficiency of institutions. At the same time, they are regarded as typical effects of concluding economic transactions (the before-mentioned Williamson (1998a, p. 388) emphasized that every problem of exchange may be interpreted as a contract, whose conclusion and execution require incurring transaction costs), but also as the effects of limited knowledge and opportunism of the parties to the transaction, as well as human natural tendency towards making mistakes (Chotkowski, 2010, p. 106). As Zbroińska (2013, p. 164) notices, those costs are created 'in every sphere of human activity, since we live in a 'world of contracts' with diverse intensity of uncertainty and disloyalty'.

2 In the new institutional economics, efficiency is an important criterion for the evaluation of operations of an organization, although it is treated differently than the so-called allocative efficiency in neo-classical economics, understood as optimization of relations between expenditures and economic effects, for the given institutional environment. In the new institutional economics, adaptive efficiency is adopted as a criterion of evaluation, understood in the context of institutional flexibility, meaning the capability of institutions to adapt to changing conditions of the environment, mostly in the aspect of reduction of transaction costs (North, 2006, p. 107). Referring to the local government sub-sector, one might assume that adaptive efficiency is the higher the more developed is the local government administration system (it is best developed in strongly-decentralized public administration systems). This stems from the fact that advanced institutions are characterized by higher adaptive capabilities (Rudolf, 2015, p. 116). 
American economist and lawyer Ronald Coase (1937, pp. 386-405) is considered the precursor of the transaction costs theory. He describes it in a scientific paper entitled The Nature of the Firm, published in 'Economica' in 1937. The theoretical conclusions it included were later broadened by Williamson (1979, pp. 233-261) in an article entitled Transaction-Cost Economics: The Governance of Contractual Relations, published in 'Journal of Law and Economics' in 1979.

Several unique characteristics can be ascribed to transaction costs. One of them is the market participants' often not being aware of their existence. Another are the difficulties related to their quantification. Consequently, they are often omitted or marginalized in the economic calculation and at the same time regarded above all things as a side effect of the concluded transactions and of transferring ownership, rather than an actual determinant of the obtained economic effects (Zbroińska, 2009, pp. 100-101). Meanwhile, Williamson (1985, p. 19) graphically demonstrated the significance and weight of transaction costs in the economy, through an analogy to the phenomenon of friction in physics: 'Transaction costs are the economic equivalent of friction in physical systems'. Just like friction in physics is a common phenomenon, every economic system entails costs of its functioning, including transaction costs. They should be treated as a counterpart of 'friction' in physical phenomena, and institutions - as a type of 'grease', which facilitates transactions.

\section{Attributes of transactions which shape transaction costs, with emphasis on the specificity of public sector}

In the context of the amount of transaction costs, attributes of transactions are of special significance. Williamson (1998a, p. 65) claims that the main determinants of transaction costs are:

- specificity of assets involved, including: physical asset specificity, human asset specificity, site or location specificity and dedicated assets specificity;

- frequency of contracting;

- uncertainty as to the behavior of the contract partner (opportunism) and the conditions of the environment (level of predictability, institutional structure etc.).

The specificity of assets usually results in specific problems in the course of execution of contracts. As examples, Kim and Mahoney (2005, p. 233) cite the risk of the hold-up problem, or the issue of opportunistic behaviors.

The specificity of assets in the context of public sector organizations allows for formulating the following postulates. First, goods and services subject to exchange within the frames of the public sector, are specific in nature and are special types of goods. Those are public goods (in the case of the local government sub-sector - local public goods). As long as private goods are such goods that while being consumed by one person they cannot be simultaneously consumed by another (rival consumption), this characteristic does not pertain to public goods. Public goods, due to their specificity, are not provided by 
the private sector at all or are provided in lower quantities as compared to social needs. At the same time, their consumption is non-rival in nature. In addition, there is a natural tendency for local government community citizens to inflate the demand for such goods, especially in the context of the apparent absence of payment for them (such are the illusory feelings of tax-payers - the effect of the so-called fiscal illusions). Both those and some other characteristics of public goods result in the fact that public goods are not standard goods. However, the authors of the most popular American handbook entitled Law \& Economics (Polish counterpart to Ekonomiczna analiza prawa) argue that transaction costs are lower in the case of standard goods and services consisting in exchange, while significantly higher in the case of exchange of goods and services of special nature (Cooter \& Ulen, 2016, p. 91).

Second, in the case of public sector, there is a significantly lower frequency of transactions than in private sector. The low frequency generates relatively higher transaction costs, including the costs of attracting business partners and negotiations.

Third, the specificity of human assets is important in public contracts. Public choice theory contains references to this. According to it, aside from the issue of market failure, the issue of government failure, and therefore public failure, arises. Consequently, both the manner and effects of operation of public organizations (including local government units) should be considered through individual preferences and choices/actions of individual entities included in their composition - so-called methodological individualism (famous theorem of James M. Buchanan: 'Every man is his own economist'). What is important, there is a natural contradiction between striving for individual efficiency and global efficiency of public policy. The so-called common good does not significantly govern political choices, which translate to particular economic decisions, but they are rather the resultant of individual motivations of politicians (e.g. in making financial decisions, local government authorities focus mainly on maximization of political support), as well as pressures of various groups of interest. Politicians attempt to maximize power when fighting for reelection, just like entrepreneurs maximize profits. This pertains to authority both in the legal (introduction of excessively detailed legislative regulations), the administrative (growth of bureaucracy), and the financial aspect (growth of public budgets). At the same time, specific lobbying groups (economic and social pressure groups), by using the mechanism of political pressure, enter into interactions with politicians, striving for shaping tax privileges, donations, subsidies, prices etc., which are most favorable for themselves. The described conditions connected to the infirmity of public decision-makers, politicization of their decisions and bureaucracy translate to uncertainty with regard to the behavior of contract partners and conditions of the environment. Igor Postula (2013, p. 73) emphasizes, that this uncertainty makes contracts incomplete, leading to higher transaction costs. 
Attributes of transactions characteristic for public sector are, above all things, the effect of the specificity of this sector as compared with private sector. Table 3 shows the impact of the specific characteristics of public sector on transaction costs.

\section{Types of transaction costs present in local government units}

One of the divisions of transaction costs often suggested in the reference literature is their division into internal and external transaction costs. The specificity of this division in reference to LGUs is demonstrated in scheme 1.

Scheme 1 accentuates two key categories of transaction costs for the local government sub-sector. First, costs stemming from execution of contracts concluded at the level: LGUs - other public entities (e.g., central administration, other LGUs). Second - contracts concluded at the level: LGUs - private entities and non-governmental organizations. In the first case, they are transaction costs related to the structure of public institutions, generated as an effect of decentralization and fiscal relations taking place among individual levels of public authority (transaction costs of intergovernmental relations) ${ }^{3}$. The second case is associated with the progressing marketization of relations within the public sector and the transaction costs associated with the process pertain among others to: the method of provision of local public goods (including the consolidation of entities rendering those services), tender procedures, public-private partnership, municipal outsourcing or privatization processes of municipal companies, etc. ${ }^{4}$.

An additional differentiation of transaction costs is introduced by Furubotn and Richter (2005, p. 43). They divide transaction costs into three categories connected to the nature and type of collaboration of the contract entities:

- market transaction costs - concern market exchange and are created in connection with conclusion of transactions in the market of goods and services; they cover the costs of acquisition of information, negotiation, securing the contract, etc.;

${ }^{3}$ According to Buchanan and Lee (2000, p. 135), centralized political structures are usually characterized by lower transaction costs due to negotiating a given profile of public policy. This stems from the fact that in centralized systems, pressure groups focus their activities mainly on the 'central decision-maker' - they do not, however, need to search for channels of access to the lower decision levels within the administration's structure.

${ }^{4}$ In public management, privatization always means the process of transferring ownership of a specific part of public assets (in the case of LGUs - communal assets) to a private entity. The issue of outsourcing of public services, however, is different. In this case, opening of a specific sphere/plane of execution for local public tasks to competitive mechanisms takes place, however, without transferring the public ownership to a private entity. The literature emphasizes that outsourcing of public services is based on the mechanism of competing for the market (and not on risk) and the associated competing of private entities for contracts concerning the provision of public services (Domberger \& Jensen, 1997, p. 68). 
- managerial transaction costs - generated within the organization, especially in the context of execution of managerial contracts and superior-subordinate relations;

- political/public transaction costs - associated with the provision of public goods by entities of the public sector as well as public decision-makers' making political decisions.

For the subject matter of this paper, of key importance are political/ public tractions costs connected not only to the costs of establishment of public institutions but also the costs of making decisions and their enforcement in public sector, as well as to the costs of production and provision of public goods. They cover, among other things, the costs of: organization, maintenance and modernization of the formal and informal public order of the given political, social and economic system, as well as the expenses for legislature, protection of the country, technical and social infrastructure, etc. (Chotkowski, 2010, p. 107).

The reference literature draws attention to the specificity of public contracts as compared with private contracts. Differences stem from the fact that the public (political) market is governed by different laws, and the decisions made on it are public choices, in which social preferences are manifested, and within which a compromise is reached between economic rationality and social justice (Zbroińska, 2009, p. 102).

Kulesza and Sześciło (2013, pp. 114-115) question the thesis of absolute superiority of contractual solutions over hierarchical relations for the public sector. In their opinion 'the public sector's contracting of services on the market instead of traditional provision by entities hierarchically subordinate to the employer is connected with certain risks. One of those is the so-called negative selection, meaning an economic phenomenon that information advantage of the seller over the purchaser (service provider over the service purchaser) may result in suppression of the better product by the worse product'.

The authors of the report Outsourcing of public services. Model of contracting of public services speak in a similar, criticizing convention in the context of dangers connected to contracting of public services by private entities. They emphasize that even if the market is competitive and there are conditions, in which, as the result of competition of private contractors, cheaper public services are obtained, in the final calculation, public administration does not always gain, and the key reason are the higher (than in the classical model of provision of public services) transaction costs, as well as costs stemming from unrealized contracts. The following conclusion can be found in the above-mentioned report: 'Private monopoly is more detrimental and more difficult to eradicate than public monopoly, for instance due to the fact, that private entrepreneurs are not subject to democratic verification through elections. Therefore, they can be more resistant to criticism and pressure from citizens' (Centrum Inicjatyw Obywatelskich, 2014, p. 8). 
Feiock (2008, pp. 2-18) (Florida State University) gives an interesting and extensive concept of division of transaction costs. Firstly, those are costs present in the context of transaction costs of intergovernmental relations, therefore costs of contracts connected to delegating of specific rights and obligations by the state to the local government (intergovernmental contracts). Examples might include: expenses for legislation specifying the scope of the delegated rights, expenses for the functioning of institutions exerting supervision and control of the state over the local government within the scope of correctness of financing and execution of the delegated public tasks etc.

Second, those are economic transaction costs. Decentralization fosters market-preserving solutions (market-preserving federalism), for instance in the context of limitation of the possibility of political intervention of the state/ central authorities on the market. In decentralized systems, it is the local government authority which decides about the level and manner of the provided public goods. Frequent is the argument that goods provided by local authorities to a greater extent correspond to citizens' preferences (preference-matching argument), and therefore higher efficiency of their allocation is present. At the same time, however, the previously-mentioned marketization of the process of production and provision of public goods usually is connected to increased transaction costs. For instance, contracting of services entails high transaction costs resulting from increasing control and inspection (Fedan, 2011, p. 214).

Another example of projects burdened with transaction costs, which are significantly higher than in the case of the traditional formula of public projects, are projects implemented in the public-private partnership system (PPP). The literature on the subject emphasizes that this form of collaboration of public with private entities is usually characterized by higher transaction costs as compared to investment projects executed traditionally by public investors. The reasons are: the long-term nature of PPP contracts, the mixed structure of ownership and financing, which is characteristic of such investments, as well as the division of risk between the public and the private partner (Dudkin \& Välilä, 2005, p. 4) 
Third, those are political transaction costs. Feiock discerns six categories for such costs: agency costs; legislative decision-making costs; uncertainty costs ${ }^{5}$; commitment costs ${ }^{6}$; sunk costs ${ }^{7}$; influence costs ${ }^{8}$.

\section{Conclusion}

The aspects shown in the paper allow indicating certain possibilities and planes of application of the postulations of transaction costs theory in the context of efficient management of LGUs finances.

First, aside from the decision-making and managerial field of local government authorities, a significant portion of external transaction costs remain, mainly ones stemming from the relation between the central authorities and LGUs, including the costs incurred by the local government in connection with the state's delegation of specific rights and obligations. The local government does not have the capability and instruments to limit such costs.

Second, in functioning of local government, of key importance, from the point of view of management, are the following planes of exchange relations (transactions) between the public and private sectors (Brol, 2013, pp. 61-62): the public sector regulates the operations of the private sector; the public sector produces public goods in aid of the private sector; the public sector provides, for a fee, goods to the private sector; the public sector purchases private goods produced in the private sector; the public and private sector jointly produce goods; the private sector provides public goods; the private sector affects public regulations. All of the described relations result in the occurrence of specific transaction costs for the local government unit and they should, at least in estimation, be accounted for in managing local government finances.

Third, local government decision-makers, by deciding to market the process of production and provision of selected public goods/services, thus making a make or buy type decision (municipal outsourcing, public-private partner-

5 Execution of a contract concluded between the principal (central authority) and the agent (LGU) is always connected to a specific level of political uncertainty. This stems from the natural conflict of political interests between such public entities. In a situation of significant divergence of the central and local priorities of public decision-makers, the costs of uncertainty burdening the contract grow significantly (Jenks, 1994, pp. 17-36).

6 This term is understood as, above all things, any and all additional costs and lost profits stemming from the undertaken obligation.

7 Those are transaction costs, often referred to as 'sunk' or lost costs, which had already been incurred, and therefore cannot be recovered. Incurring them may be suspended at the time of cessation of e.g. provision of a public service or execution of an investment, which requires incurring the said costs. In the case of LGUs, costs of maintenance of city stadiums might be used as an example.

8 Those are transaction costs associated not only with impacting the public opinion (in the case of LGUs - the local voters), but also the costs of political lobbying, public relations, territorial marketing, etc. 
ship, securitization of assets, privatization of public sector enterprises, etc.), in their economic calculations should allow for the risk of a significant increase of transaction costs.

Fourth, in the processes of efficient local finance management, one should allow for solutions used for minimization of transaction costs on three decision-making stages (Cooter \& Ulen, 2016, p. 88), i.e.: looking for an exchange partner; concluding the transaction and enforcement of the terms of the transaction. In this system, in Poland one should begin monitoring and minimizing LGU transaction costs.

Fifth, in line with the postulations of the transaction costs theory, local government decision-makers, in their economic calculations, should account for the risk connected to the opportunism of local government administration employees, including the possibility of incomplete or distorted presentation of information important from the point of view of the financial decisions made.

\section{References}

Brol, M. (2013). Przyczyny trudności we współpracy sektora publicznego i prywatnego. Studia Ekonomiczne. Uniwersytet Ekonomiczny w Katowicach, 129.

Buchanan, J.M. \& Lee, D.R. (2000). On a fiscal constitution for the European Union. In The Collected Works of James M. Buchanan, vol. 18. Indianapolis: Liberty Fund.

Centrum Inicjatyw Obywatelskich. (2014). Outsourcing ustug publicznych. Model kontraktowania ustug publicznych. Retrieved 10.01.2017 from http://www. zlecaniezadan.pl.

Chotkowski, J. (2010). Instytucje rynkowe i koszty transakcyjne - kluczowe pojęcia nowej ekonomii instytucjonalnej. Roczniki Nauk Rolniczych, 97(2).

Coase, R.H. (1937). The nature of the firm. Economica, 4(16). doi:10.1111/j.1468-0335.1937.tb00002.x.

Commons, J.R. (1957). Legal foundations of capitalism. Madison: University of Wisconsin Press.

Cooter, R., \& Ulen, T. (2016). Law and economics, 6th edition. Addison-Wesley.

Domberger, S. \& Jensen, P. (1997). Contracting out by the public sector: theory, evidence, prospects. Oxford Review of Economic Policy, 13(4). doi:10.1093/ oxrep/13.4.67.

Dudkin, G. \& Välilä, T. (2005). Transaction costs in public-private partnerships: a first look at the evidence. EIB Economic and Financial Reports, 03.

Fedan, R. (2011). Zarządzanie publiczne w procesie kreowania rozwoju lokalnego i regionalnego. Nierówności Spoteczne a Wzrost Gospodarczy, 20.

Feiock, R.C. (2008). A transaction cost theory of federalism. Local Governance Research Laboratory Working Paper. Retrieved 10.01.2017 from http://localgov.fsu.edu. 
Furubotn, E.G., \& Richter, R. (2005). Institutions and economic theory. The contribution of the New Institutional Economics. Ann Arbor: University of Michigan Press. doi:10.3998/mpub.6715.

Jenks, S. (1994). County compliance with North Carolina's solid waste mandate: a conflict based model. Journal of Federalism, 24(2). doi:10.1093/oxfordjournals.pubjof.a038133.

Kim, J. \& Mahoney, J.T. (2005). Property rights theory, transaction costs theory, and agency theory: an organizational economics approach to strategic management. Managerial and Decision Economics, 26(4). doi:10.1002/ mde.1218.

Krynicka, H. (2006). Koncepcja Nowego Zarządzania Publicznego w sektorze publicznym (New Public Management). Studia Lubuskie, 2.

Kulesza, M. \& Sześciło, D. (2013). Polityka administracyjna i zarządzanie publiczne. Warszawa: Wolter Kluwer.

Lubińska, T. (Ed.). (2009). Nowe Zarządzanie Publiczne - skuteczność i efektywność. Budżet zadaniowy w Polsce. Warszawa: Difin.

Musialik, G. \& Musialik, R. (2013). Związek sektora publicznego i rynkowego. Studia Ekonomiczne. Uniwersytet Ekonomiczny w Katowicach, 156.

North, D.C. (1990). Institutions, institutional change and economic performance. Cambridge: Cambridge University Press.

North, D.C. (1994). Economic performance through time. American Economic Review, 84(3).

North, D.C. (2006). Understanding the process of economic change. New Delhi: Academic Foundation.

Postuła, I. (2013). Nadzór korporacyjny w spótkach Skarbu Państwa. Warszawa: Wolters Kluwer.

Rada Ministrów. (2016). Sprawozdanie z wykonania budżetu państwa za okres od 1 stycznia do 31 grudnia 2015 r. Retrieved 10.01.2017 from http:/ /www.mf.gov. pl.

Rosińska, M. (2008). Analiza ekonomiczna przedsiębiorstwa w oparciu o teorie instytucjonalne - koncepcja „instytucjonalizmu organizacyjnego przedsiębiorstw". Acta Universitatis Lodziensis Folia Oeconomica, 221.

Rudolf, W. (2015). Możliwości wykorzystania nowej ekonomii instytucjonalnej w rozwoju sektora publicznego. Zarządzanie Publiczne, 2(30). doi:10.4467/2 0843968ZP.15.010.3581.

Sokołowicz, M.E. (2013). Zagadnienie bliskości w badaniach nad rozwojem terytorialnym. Podejście instytucjonalne. In: A. Nowakowska (Ed.). Zrozumieć terytorium. Idea i praktyka. Łódź: Wydawnictwo Uniwersytetu Łódzkiego.

Supernat, J. (2003). Administracja publiczna w świetle koncepcji New Public Management. Zeszyty Naukowe Wyższej Szkoty Administracji Publicznej w Biatymstoku, 2.

Szmitka, S. (2012). Teoretyczne uwarunkowania wyższości własności prywatnej nad publiczną. Warmińsko-Mazurski Kwartalnik Naukowy. Nauki Spoteczne, 4. 
Ustawa z dnia 29 sierpnia 2007 r. o finansach publicznych [Public Finances Act of August 27, 2009] (Dz. U. 2016 poz. 1870).

Veblen, T.B. (1899). The theory of the leisure class: an economic study of institutions. London: The Macmillan Company.

Wilkin, J. (Ed.). (2012). Teoria wyboru publicznego. Gtówne nurty i zastosowania. Warszawa: Scholar.

Williamson, O.E. (1979). Transaction-cost economics: the governance of contractual relations. Journal of Law and Economics, 22(2).

Williamson, O.E. (1985). The economic institutions of capitalism. Firms, markets, relational contracting. London: Collier Macmillan Publishers.

Williamson, O.E. (1998a). Ekonomiczne instytucje kapitalizmu. Firmy, rynki, relacje kontraktowe. Warszawa: PWN.

Williamson, O.E. (1998b). Transaction cost economics: how it works; where is headed. De Economist, 146(1). doi:10.1023/A:1003263908567.

Woźniak-Jęchorek, B. (2014). J.R. Commons vs. O.E. Williamson - dwie szkoły instytucjonalne i ich dorobek z punktu widzenia ekonomiki rynku pracy. Studia Prawno-Ekonomiczne, 92.

Zalewski, A. (Ed.). (2007). Nowe Zarzadzania publiczne w polskim samorzadzie terytorialnym. Warszawa: Szkoła Główna Handlowa.

Zbroińska, B. (2009). Publiczne koszty transakcyjne instytucji systemu podatkowego. Gospodarka Narodowa, 11-12.

Zbroińska, B. (2013). Wkład ekonomii kosztów transakcyjnych i teorii kontraktów do nauki o zarządzaniu. Studia i Materiaty. Miscellanea Oeconomicae, $17(2)$.

\section{Acknowledgements}

Author contributions: author has given an approval to the final version of the article.

Funding: this research was fully funded by the University of Bialystok, Faculty of Economics and Management, Department of Treasury statutory sources.

Note: the results of this study were presented at 9th International Conference on Applied Economics Contemporary issues in Economy (June 22-23, Torun, Poland). 


\section{Appendix}

\section{Table 1.}

\section{Theoretical concepts coherent with the paradigm of the new institutional economics, specifically for public sector and local government units}

\footnotetext{
Theoretical concept

Theoretical assumptions, key from the standpoint of financial decisions made in local finances

- the basic characteristic of human existence is the permanent necessity to make specific choices (in the case of local government decision-makers - public/political choices) in conditions of various limitations, including institutional limitations;

- the manner and the effects of operation of public organizations (including LGUs) should be considered through individual preferences and choices;

Public choice

- the issue of inefficiency (unreliability) of the government (government failure) and the assotheory ciated infirmity of public decision-makers is of key importance - politicians do not follow the public interest, but their own, particular goals (e.g., reelection criterion);

- there is a natural contradiction between striving for individual efficiency and the global efficiency of the public coordination policy;

- the infirm mechanism of transmission from the political to the public administration zone (bureaucracy follows their own interests, i.e., reinforcement of their own position in the form of budget maximization) (Musialik \& Musialik, 2013, p. 294).

- relations between the parties to a contract representing specific demeanors are important, i.e., the principal, who on the basis of a formal contract engages another entity, described as an agent, to act on principal's behalf in a specific area of decision-making issues;

- there is a clear discrepancy between the objectives implemented by the principal and the agent - each of them maximizes their own utility function;

Theory

of agency/principal-agent

Property rights theory

- in the field of the local government, this theory is used to study the relations of inferiority, superiority and control in LGUs as well as the relations between the individual levels of authority (Sokołowicz, 2013, pp. 22-23), including the relations between the central authority (principal) and the local government authority (agent), the relations between the local government authority (principal) and managers of public enterprises (agents), or the relations between citizens - voters (acting as the collective principal) and the representatives of public administration (agents);

- the effect of the created relations are the rising costs of agency, limiting the efficiency of per formance of ownership functions and decreasing the efficiency of functioning of the local government sub-sector.

- an important role in social-economic processes is played by ownership relations - this also applies to social-economic processes, which take place in local systems;

- domination of private ownership in the economy fosters competitiveness, enforces higher efficiency for utilization of resources as well as pro-innovative activities;

- processes of privatization, i.e., transferring ownership from the public sector (in the case of LGUs - communal ownership) to the private sector, should take place in those areas of local governmental activity, in which private ownership has comparative advantages (Szmitka, 2012, pp. 123-127).
} 


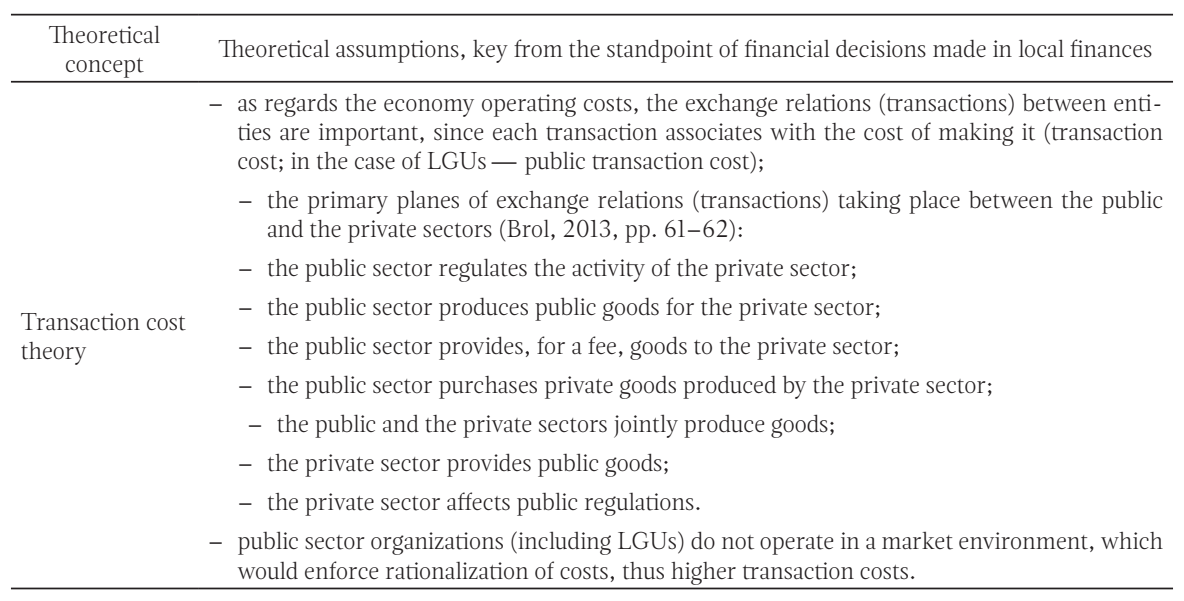

Source: Own study.

Table 2.

Characteristics of efficient public management versus selected theoretical concepts of the New Institutional Economics

\begin{tabular}{|c|c|c|c|c|}
\hline Characteristic & $\begin{array}{c}\text { Public choice } \\
\text { theory }\end{array}$ & $\begin{array}{c}\text { Theory } \\
\text { of agency }\end{array}$ & $\begin{array}{l}\text { Property } \\
\text { rights theory }\end{array}$ & $\begin{array}{l}\text { Transaction } \\
\text { cost theory }\end{array}$ \\
\hline limitation and rationalization of public expenses & $\mathrm{x}$ & $\mathrm{x}$ & $\mathrm{x}$ & $\mathrm{x}$ \\
\hline focus on result/effect & $\mathrm{x}$ & $\mathrm{x}$ & $\mathrm{x}$ & $\mathrm{x}$ \\
\hline focus on the goods and public services consumer & $\mathrm{x}$ & $\mathrm{x}$ & - & - \\
\hline competition & $\mathrm{x}$ & $\mathrm{x}$ & - & $\mathrm{x}$ \\
\hline contracting out & $\mathrm{x}$ & $\mathrm{x}$ & - & $\mathrm{x}$ \\
\hline privatization & $\mathrm{x}$ & - & $\mathrm{x}$ & $\mathrm{x}$ \\
\hline decentralization & $\mathrm{x}$ & $\mathrm{x}$ & & $x$ \\
\hline
\end{tabular}

Source: Own study. 
Table 3.

Impact of the specificity of public sector as compared with private sector on transaction costs

\begin{tabular}{lc}
\hline \multicolumn{1}{c}{ Characteristics specific for the public sector } & $\begin{array}{c}\text { Impact of the given characteristic on the amount } \\
\text { of transaction costs }\end{array}$ \\
\hline $\begin{array}{l}\text { specific/non-standard goods provided by the public } \\
\text { sector }\end{array}$ & higher TC \\
publicness of information and financial economics \\
strictly regulated legal infrastructure \\
$\begin{array}{l}\text { difficulties in quantification of the effects of operation } \\
\text { the balance of public finances and transfer of public } \\
\text { resources are dominated by intervention of the state } \\
\text { and designated by state authorities } \\
\text { in the decision-making process, shorter time horizon } \\
\text { is taken into account - which is the effect of rotation } \\
\begin{array}{l}\text { in office of local government authorities } \\
\text { mutual benefits of the parties to contracts are not ful- } \\
\text { filled simultaneously (exchange is distributed over time) } \\
\text { bureaucratic and formalized structure } \\
\text { political nature of decisions }\end{array} \\
\text { broad scope of supervision }\end{array}$ \\
\hline
\end{tabular}

Source: Own study.

Scheme 1 .

Internal and external transaction costs for functioning of local government units

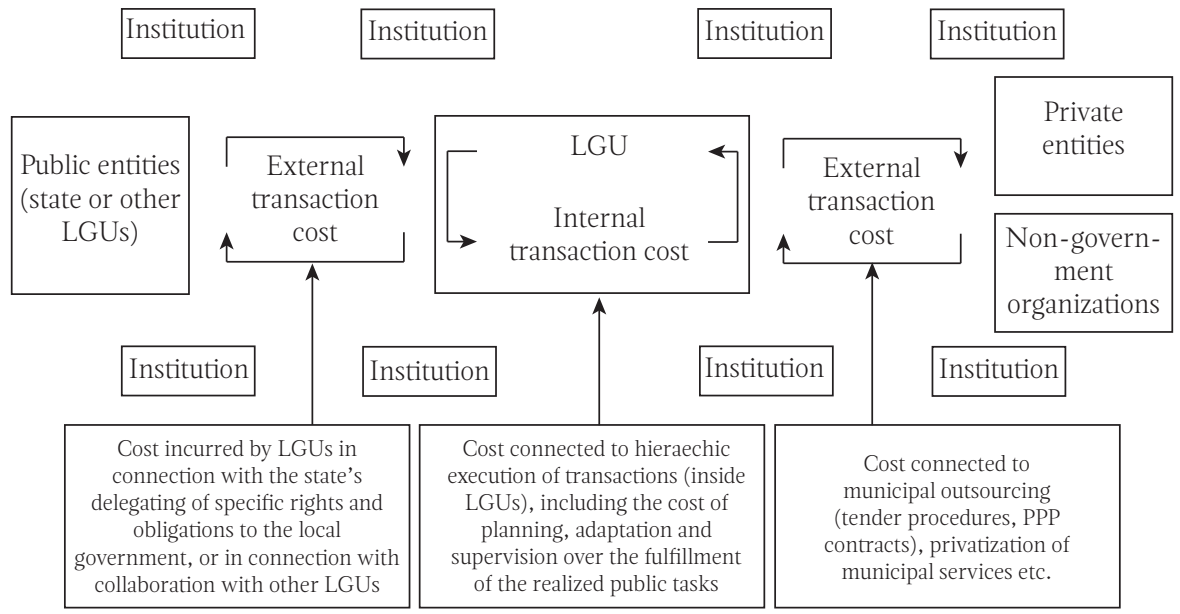

Source: Own study. 
